\title{
ERRATUM
}

\section{Erratum to: Effects of Heat Treatment Processes on Corrosion Resistance of Epoxy-Coated Rebar Steel}

Seifollah Nasrazadani • Venkata Venkatesh Nagulakonda • Javier Barnes •

Andres Garcia • Amaal Al-Shenawa • Nandika Ann D'Souza

Published online: 9 September 2016

(C) ASM International 2016

Erratum to: J Fail. Anal. and Preven.

DOI 10.1007/s11668-016-0161-7

In the initial online publication, Seifollah Nasrazadani's family name and given name were interchanged. The name has been corrected in the publication as shown in this erratum.

The online version of the original article can be found under doi:10.1007/s11668-016-0161-7.

S. Nasrazadani $(\varangle) \cdot$ V. V. Nagulakonda $\cdot$ J. Barnes University of North Texas - Engineering Technology, 3940 N. Elm, Denton, TX 76207, USA

e-mail: nasr@unt.edu

A. Garcia · A. Al-Shenawa - N. A. D’Souza

University of North Texas - Mechanical \& Energy Engineering,

3940 N. Elm, Denton, TX 76207, USA 